in schools, particularly in West Africa. Of the 8,315 overseas visitors in Britain in 1962-63 assisted by the Council, 1,971 were in science and technology, 1,260 in medicine, 1,399 in social science and 2,404 in education. Under the Commonwealth Scheme for university interchange, 73 awards were made to meet the cost of travel during 1962-63-41 being to university teachers on study leave, 11 to distinguished scholars invited by universities for short visits, and 21 to postgraduate university research workers holding research grants. Under the Foreign Scheme, 117 short visits by senior members of university staff were arranged, 2 longer visits by guest professors and lecturers from Britain to Germany and 79 visits for younger research workers.

\title{
THE COMMONWEALTH SCHOLARSHIP AND FELLOWSHIP PLAN
}

$\mathrm{T}$ HE third annual report of the Commonwealth Scholarship and Fellowship Plan* includes for the first time in the appendixes a special section of Commonwealth visiting fellowships and other senior awards under the Plan. Five visiting fellowships, two in Britain, two in Canada and one in India, were taken up during the year, and two Prestige fellowships, one in India and one in Australia. It is now expected that the total of 1,000 awards at any one time anticipated at the Commonwealth Education Conference at Oxford in July 1959 will be reached about the time the third Commonwealth Education Conference meets at Ottawa in August 1964, although more than 1,000 awards were made within a few months of the Oxford Conference.

During the year, including the seven fellowship awards already noted, 820 Commonwealth scholars held awards, as counted in the first terms of the awarding countries' academic year, compared with 729 in the previous year, when the total was compiled on a different basis. A significantly smaller proportion of awards was held at the undergraduate-level and there was a considerable proportionate increase in awards for higher degrees. In Britain, 467 Commonwealth scholars held awards at universities and colleges in the first term of the academic year 1962-63, and of these, 183 took up their awards in October. Extensions of tenure of scholarships were granted to 165 scholars, including 138 for studies extending into a third year, and the Commonwealth Scholarships (Amendment) Act which became law on February 28, 1963 , by removing the rigid limit of 500 awards at any

* Third Annual Report of the Commonwealth Scholarship and Fellowship Plan for the period ending 31 March, 1963. Prepared by the Association of Commonwealth Universities for the Commonwealth Education Jiaison Committee. Pp. 70. (London: H.M.S. O., 1963.) 5s. one time, enables the Commission to make fuller use of the funds at its disposal. Of the 142 scholars whose awards have come to an end since the beginning of the scheme, 41 have qualified for doctorates, 32 for master's degrees, 25 for postgraduate diplomas, 15 for first degrees and 11 for higher medical qualifications. About half these scholars have taken up academic posts on return to their own countries, and about 51 of the others have been granted permission to defer return home for a named period, with the approval of the nominating ageney.

The report expresses warm appreciation of the work of the Working Party set up by the Committee to consider the day-to-day operation of the Plan, but the report does not consider justified the criticisms levelled at the Plan by many of the developing countries at the second Commonwealth Education Conference at New Delhi on the grounds that awards for undergraduates are not available. Few nominations have, in fact, been received in Britain from overseas countries for such awards, but more such nominations are expected in 1964 in view of awards for technical education being made by Pakistan and Ceylon. Some countries expressed concern at New Delhi and in the last annual report lest extension of tenure of beyond two years to enable scholars to complete research for a doctorate should decrease the number of new awards available each year. In Britain the amended Act meets this situation, and other countries which have not yet reached their target number of awards may balance extensions against awards given for only one year. However, no clear solution is seen in the report to the recurring problem of ensuring that scholars fulfil their undertaking to return to their own country on completing the tenure of their scholarships. Any enforcement can only rest with the nominating country.

\section{ELECTROPHORESIS}

\begin{abstract}
A SYMPOSIUM on "Electrophoresis" was held in the Bacteriology Department, Anderson College, University of Glasgow, on December 12, 1963. This was the third meeting in a series of informal symposia organized. by the Department of Scientific and Industrial Research as part of their Scottish Research Laboratories Mutual Assistance Scheme. The meeting was attended by some 120 delegates from all parts of Scotland.

The chairman, Prof. R. G. White (Bacteriology Department, University of Glasgow), opened the proceedings and gave a short talk on "Immunoelectrophoresis", using recent work to illustrate the differences in antisera produced by the injection of different types of preparations of similar antigens. Prof. White emphasized the importance of recognizing these differences when antisera were being used as analytical reagents.

Dr. J. R. Norris (Bacteriology Department, University of Glasgow) described work in progress on the antigenic and enzymatic composition of Bacillus cereus cells and the changes which occur at sporulation in this bacterium. Particular attention was directed to the use of polyacryl-
\end{abstract}

amide gel electrophoresis, and Dr. Norris discussed some of the characteristics of this medium when used for sheetgel electrophoresis. A method had been developed for combining polyacrylamide electrophoresis with antigenantibody diffusion analysis in agar. The resulting discussion ranged over various aspects of the handling of the gel and the comparison of agar, starch and polyacrylamide as bases for electrophoresis.

High-voltage electrophoresis was discussed by Dr. G. Leaf (Biochemistry Department, University of Glasgow), who related a theoretical treatment to the characteristics of the technique encountered in practice. Discussion centred on the advantages of high-voltage electrophoresis over other tochniques, such as thin-layer chromatography, on voltage-levels suitable for use in various media and gels and on factors influencing diffusion of components during separation.

Dr. W. Manson (Hannah Dairy Research Institute) described the elegant system which he operated for density gradient electrophoresis using separation in a sucrose gradient to fractionate casein preparations. Dr. Manson 
demonstrated the equipment which he used and presented results which emphasized the value of the method for preparative purposes. In discussion it was pointed out that the method allowed of considerable variation in conditions. Urea, for example, could be incorporated in the system.

Dr. B. L. Cohen (Genetics Department, University of Glasgow) discussed two-dimensional separation techniques and described a method in which paper electrophoresis in one direction is followed by chromatographic separation at right angles. Dr. Cohen's apparatus was more simple than that usually used for this purpose and gave excellent soparation at relatively low-voltage gradients. The method was being used for 'finger-printing' of albumin. Discussion was wide-ranging covering the use of two-dimensional methods for peptide separation, difficulties in sample elution from various paper supports, the use of glass fibre papers and the characteristics of separation in paper as opposed to other media.

Column electrophoresis was described by Dr. A. Fleck (Biochemistry Department, University of Glasgow). The merits of this technique for preparative work were the subject of much discussion, several delegates commenting on the factors involved in loss of resolution during elution. Dr. Loening (Botany Department, University of Edinburgh) described, in this connexion, a method which he had developed for withdrawing samples continuously from polyacrylamide columns through a hypo. dermic needle.

Demonstrations of two-dimensional electrophoresis, immunoelectrophoresis, starch-gel and polyacrylamide-gel electrophoresis were supplied by Dr. B. L. Cohen and Dr. J. R. Norris.

\title{
ARCHAOLOGY IN SARAWAK
}

$\mathrm{T}$ HE work of Tom Harrisson, curator of the Sarawak Museum, has not obtained as much publicity as it should. The excavations in the great cave at Niah, Borneo, are of real importance, and cultures from the Iron Age back to the Middle Palæolithic have been discovered*. Moreover, Niah is not the only site in that part of the world, and Harrisson has examined a number of others, including one where rock-wall paintings occur. These may not be of any vast antiquity but are none the less of considerable interest.

In Borneo the transition from the stone age to that of metal can still be studied. Harrisson himself during the Japanese War landed by parachute among the Kelabits far in the interior. These people were culturally still at the end of the stone age, using stone hammers and anvils such as are used to-day in Central Now Guinea. In their folklore there is a story of a miracle transformation when suddenly a man appeared with the first iron tool and was able to multiply enormously his agriculture in one splendid day. One can recall folklore tales in Western Europe which date to events as long ago as the Copper Age; but this Borneo example is of particular interest and must refer to the first introduction of iron into the district as the result of trade. When the late Baron von Hügel first visited Fiji he found in the interior a man making stone

* 100,000 Years of Stone Age Culture in Borneo ; paper by Tom Harrisson D.S.O., O.B.E., read to the Commonwealth Section of the Royal Society of Arts. tools; when he returned a year or two later the man was dead and in his place was a blacksmith!

Harrisson claims that immediately prior to the Chalcolithic and Neolithic levels there is one containing a Mesolithic industry and still earlier others containing Upper Palæolithic tools. The use of such words as palæolithic-even upper palæolithic-is, of course, right and proper. But any further attempt to compare these distant cultures with those of Western Europe is to be deplored at our present stage of knowledge. Harrisson does not fall into this trap. So often has the word Mousterian been applied to various far-flung cultures that it has lost its meaning. If necessary a local succession with local names should be built up; later, when connexions, if any, have been demonstrated with other known cultures these could be dropped.

At Niah in one of the deeper Upper Palæolithic levels a young Homo sapiens boy was unearthed. Harrisson claims that a carbon-14 date of 38,000 B.c. has been obtained. One must hope such an early date for Homo sapiens in that particular area will be duly checked and further finds made. Borneo to-day has a rich and varying eulture, and clearly it also has a most interesting past stretching back to Middle Stone Age times. The Sarawak Museum is fortunate in having such an energetic and active curator, and Harrisson is to be congratulated on what he has already accomplished.
M. C. BURKITT

\section{SPREAD-F IN THE IONOSPHERE AND THE NEUTRAL PARTICLE DENSITY OF THE UPPER ATMOSPHERE}

\author{
By DR. G. G. BOWMAN \\ Department of Physics, University of Queensland, Brisbane
}

\begin{abstract}
$\mathrm{A}^{\mathrm{N}}$
$\mathrm{N}$ investigation of the variation in the occurrence A of Spread- $F$ throughout the year at mid-latitude stations (both northern and southern hemispheres) suggests that the variation is related to the position of the Earth in its orbit around the Sun. This relationship becomes apparent after allowance is made for a seasonal effect which results from Spread- $F$ being predominantly a night-time phenomenon.

This analysis has used data from 3 pairs of stations. The stations of each pair have approximately the same magnetic dip, but are located in opposite hemispheres. Details are contained in Table 1.

Diurnal variations of Spread- $F$, at the Japanese stations, have been determined from these data. Occurrence is restrieted almost entirely to the night hours (94 per cent
\end{abstract}

between ground sunset and ground sunrise). Fig. 1a shows a histogram using all data from the three Japanese stations. This can be compared with the histogram for a southern hemisphere station (Hobart, magnetic dip $72^{\circ}$ ) for 1952 in Fig. 1b, which has been drawn using data published previously ${ }^{1}$. Figs. $\mathrm{l} a$ and $b$ also show the diurnal variation of the neutral particle density of the

$\begin{array}{cccc}\text { Station } & \begin{array}{c}\text { Magnetic } \\ \text { dip }\end{array} & \begin{array}{c}\text { Table } 1 \\ \text { No. of } \\ \text { years data }\end{array} & \text { Data source } \\ \text { Japan } & 61 & 16 & \text { Ionospheric data in Japan } \\ \text { Waakkanai } & 55 & 16 & , ", \\ \text { Akita } & 48 & 16 & , " \\ \text { Yamagawa } & & 12 \cdot 5 & \text { I.P.S. series } D \\ \text { Australia } & 64 & 19 \cdot 5 & \text { Original ionograms } \\ \text { Canberra } & 57 & 10 \cdot 5 & \text { T.P.S. series } D \\ \text { Brisbane } & 46 & & \end{array}$

